\title{
Efficiency of gamma radiation technology in decontamination of wastewater from Soba Station-Khartoum Sudan
}

${ }^{\text {a }}$ Mahdi Haroun ${ }^{*}$, b Tisser Khalid, ${ }^{\mathrm{b}}$ Abdelazim Mohd Altawil, c Gammaa Abdelgadir Mohd Osman, ${ }^{\mathrm{b}}$ Eiman Elrashid Diab

a Department of Environmental Health College of Health Sciences Jumeira University Dubai, UAE,

b Environment, Natural Resources, and Desertification Research Institute (ENDRI), National Center for Research, Khartoum, Sudan, ' Sudan Academy of Sciences, Khartoum, Sudan.

\begin{tabular}{c|l}
$\begin{array}{c}\text { Authors' } \\
\text { Contribution }\end{array}$ & $\begin{array}{l}\text { Haroun, M. \& T. Khalid wrote the introduction, methodology, Gamma Radiation, and results and discussion and } \\
\text { conclusions, A, M. Altawil carried out experimental part of Gamma Radiation and advised on radiation } \\
\text { technology, G. A. M. Osman collecting data and worked on the development of radiation dose with different pH } \\
\text { and made the comparisons and E. E. Diab wrote about COD \& BOD, different physicochemical parameters }\end{array}$ \\
\hline $\begin{array}{c}\text { Article } \\
\text { History }\end{array}$ & $\begin{array}{l}\text { *Corresponding email address: mahdikotsh@gmail.com Digital Object Identifier (DOI): https://doi.org/10.33865/wjb.005.03.0334 } \\
\text { Received: 19 April 2020, Revised: 27 June 2020, Accepted: 15 July 2020, Published Online: } \mathbf{3 0} \text { August 2020 }\end{array}$ \\
\hline
\end{tabular}

\section{ABSTRACT}

In Sudan the expense of municipality treatment is expanding with more strict environmental obligations. Radiation technology for handling of industrial and domestic water supply is presently under study in many countries. The expenses for the wastewater treatment by radiation technology are comparable with that of the other modern technology of treatment systems. This study focuses on using of various radiation doses to handle samples of municipal wastewater collected from Soba wastewater station south of Khartoum-Sudan. The experimental results confirmed that some physicochemical parameters like pH, D0, BOD5, COD, TSS, FOG, and Total phenols were decreased with increasing absorbed doses. Other parameters like Electrical conductivity (EC) and Hardness were not affected by radiation doses. TDS, turbidity decreased up to $50 \mathrm{~K}$ rad and then increased with increased in radiation doses. All parameters are within the permissible level in Sudan for discharge to surface water. Gamma-irradiation has shown to be effective in removing organic contaminants from the sewage water and sludge. Gamma-irradiation opens door for possible reuse of irradiated sewage water and sludge. The whole experimental issues involving the management of disposed materials must be put in mind when we are assessing the benefits of applying technology of radiation for treating all municipality issues in Khartoum city.

Keywords: Soba municipal, gamma radiation, chemical oxygen Demand, wastewater, biochemical oxygen demand, breakdown.

I NTRODUCTION: Increasing industries and development has led to the discharge of toxic effluents to water bodies' worldwide. In many countries over the world, these discharged effluents are used for planting targets due to the shortage of rainwater for agriculture (Perveen et al., 2012 ;Rehman et al., 2015). The municipal treatment plant is always looking for new knowledge to deal with wastewater. The new process should have benefits in decreasing the vital price for waste handling. The sewerage works in many countries, are high in price regarding other treatment' services. The establishment of small units in a specific area, will assist in dropping the charge of works. Generally, technology of radiation is an energy progressive practice, offered for social practice, although frightened being environmentally unsafe and risky. Using this technology for treating of wastewater and domestic water supply is present in low levels of investigation. The expenses for the wastewater treatment by radiation technology are comparable with that of the other modern technology of treatment systems. Technology of radiation is a process of utilization of energy to generate a valuable variation in a substance, such as decontamination. The quantity of energy of radiation captivated in a substance lays on the physicochemical state of the substance and on the kind and energy dissemination The utilization of radiation in municipal treatment requires to attain a enough uniform absorption of doses. The elements like kind of radiation, distribution of energy, penetration ability into the media, the geometry, and radiation-water configuration, and the ratio of thickness of water.

Biological phase treatment: Recent years several reports have been come out with the prospective route of radiation energy in

the municipal plant. The logic for exploiting radiation in treating of municipal waste lays on the following ideas (Salvatore et al., 2009).

a) Radioactivity demolishes microflora and this characteristic is useful, because it will keep pathogen in an inactivation mode.

b) Radioactivity is able of changing the composition of organic particles, therefore playing greater role in the reduction of pollution parameters (BOD \&COD).

c) Radioactivity is able of changing the physiochemical properties of suspended particles, leading to settling of sludge through accumulation of sludge in compact form with high ability precipitate.

Reaction of microflora with radioactive pulses in treating municipal wastes: Physicochemical aspects like temperature and radiation, and biological and physiological aspects play a vital role in the reaction of Microflora to offered doses (Rehman et al., 2015).

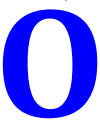

BJECTIVES: a) To assess the potentiality of gamma radiation method in disinfection of wastewater

b) Studying the degree of removal of contamination parameters like $\mathrm{pH}$, electrical conductivity (EC), turbidity, Hardness, TSS. TDS, BOD, COD and fat, oil, and grease (FOG).

c) To assess the physicochemical characteristics of municipal wastewater before and after the application of gamma; and

d) To establish the ideal doses for gamma of wastewater. was conducted in the Soba wastewater treatment plant located at southern part of Khartoum State (lat.! 
$5^{\circ} 36^{\prime}$, long. $32^{\circ} 33^{\prime}$, Alt.380 m). The station is about half kilometer from the eastern border of the Alazahri area. The plant serves all areas in southern Khartoum in addition to the hospitals and some part of the industrial area. The population in this area is about 2 million people.

Collection of sample: Samples of effluent of investigated wastewater were obtained from Soba wastewater station in two events (months): May and December (2013) where biological oxygen demand in five days (BOD5) were estimated as $110 \mathrm{mg} / \mathrm{L} \& 80$ respectively. The samples were collected from the effluent flowing from the inlet of the principal settling tank by using various kinds of fresh and sterilized glass bottles containers $(500 \mathrm{ml})$ and transported to the laboratory in ice container till the time of analysis. $\mathrm{pH}$ was immediately measured in the field with the aid of portable $\mathrm{pH}$ meter.

Equipment of irradiation: The industrial device irradiator Gamma Cell 220 used in this study was originally manufactured by Atomic Energy of Canada Limited (AECL). It was developed for high dose rate gamma radiation researches and studies. This device supplied with 60Co doubly encapsulated in aluminum and stainless-steel tubes, fixed within a lead shield, and the operator is not exposed to the emitted radiation. The Gamma Cell exposure chamber has a cylindrical geometry with $20.3 \mathrm{~cm}$ height and $7.5 \mathrm{~cm}$ radius. The device has a calculated dose rate of two $\mathrm{M} \mathrm{rad} / \mathrm{hr}$ and radioactivity of $50 \mathrm{kCi}(\mathrm{rad}$ is amount of radiation that releases an energy of 100 ergs per gram of matter). Samples were arranged in the cylindrical irradiation chamber. This room moved vertically down to the radiation sources of $\mathrm{Co}^{60}$ as roods rotate around the room to supply a homogenous dose for all samples (figure 1).

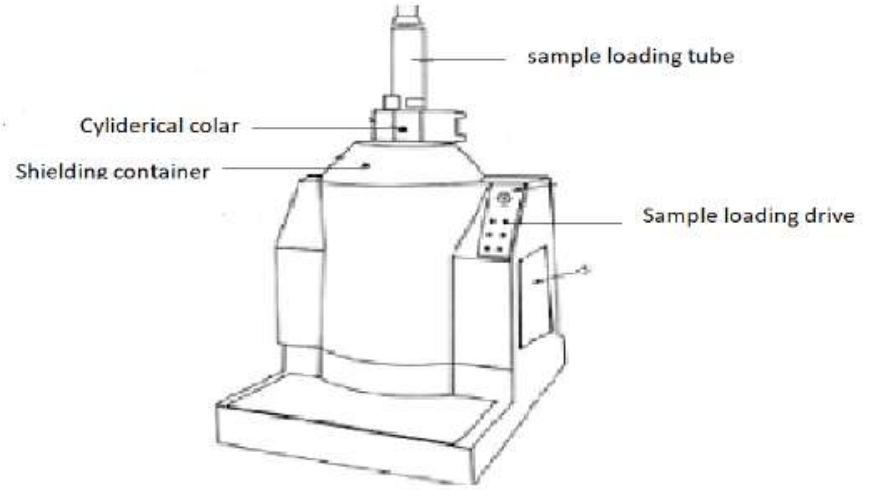

Figure 1: Irradiator gamma cell 220.

The doses used were $0,10,25,50,100,200,300,400$, and $500 \mathrm{k}$ $\mathrm{rad}$, an average of three samples exposed to the same absorbing dose was taken. The time of irradiation for these dosages was 0 , $3,7.5,15,30,60,90,120$, and $150 \mathrm{~min}$. respectively where:

Absorbing Dose (D) = Dose Rate (rad/min.) X Irradiation time (min) Analytical methods: The wastewater was examined to measure the following physicochemical parameters $\mathrm{pH}, \mathrm{EC}, \mathrm{DO}$, COD, BOD, TDS, TSS, FOG, turbidity, hardness and phenolic compounds. Two sampling events were performed, one in May $(1 / 05 / 13)$ and the other one on December (1/12/13) respectively. Samples were examined on the same laboratory \& on the same day. The procedure of collection of samples and testing were performed according to the methods explained in American Public Health Association. BOD, COD, TDS, and TSS samples were accumulated in $250 \mathrm{~mL}$ polyethylene bottles and preserved with concentrated sulfuric acid $(\mathrm{pH}<2)$. The DO samples were kept in $300 \mathrm{~mL}$ bottles with $1 \mathrm{~mL}$ of an alkaline azide solution as preserved substance $\left(1 \mathrm{~mL}\right.$ of $\mathrm{MgSO}_{4}$ solution and $1 \mathrm{~mL}$ of concentrated $\mathrm{H}_{2} \mathrm{SO}_{4}$ ). Before transportation the samples were preserved in an ice box $<4^{\circ} \mathrm{C}$. Transport of the samples occurred within six hours to the testing laboratory and stored below $4^{\circ} \mathrm{C}$ in a refrigerator until usage. DO samples were examined immediately after reaching the laboratory. The $\mathrm{pH}$ and DO were measured in situ. The $\mathrm{pH} \&$ DO was measured with a portable pH-meter and DO probe respectively. In the laboratory the DO was analyzed by titration with a standard sodium thiosulphate using starch solution as an indicator. COD was measured according to open reflux method with acidified standard potassium dichromate titrated with ferrous ammonium sulfate within 24 hours from sampling. Standard Methods for Examination of Water and Wastewater was used for determination of Biochemical Oxygen Demand (BOD5). FOG were measured by method using n-hexane as the extraction solvent, and phenolic compounds determined by using Folin and Denis (1915).

12 ESULTS AND DISCUSSION: Radioactivity has a violent influence on the organic substances in the wastewater, -due to the intense action of the pulses of energy that produced by gamma radiation which alter the properties of contaminants in the wastewater (Abo-El-Seoud et al., 2004). The outcomes were found in the untraceable stages for most of the examined samples, but there were some examined samples which did not react to the radiation energy due to the presence of inorganic substances (Abo-El-Seoud et al., 2004).

The pH measurement: Figure 2 explain the $\mathrm{pH}$ values throughout the two events (May and December), so when applying radiation dose, the $\mathrm{pH}$ increasing with the rose in radiation absorbed doses.

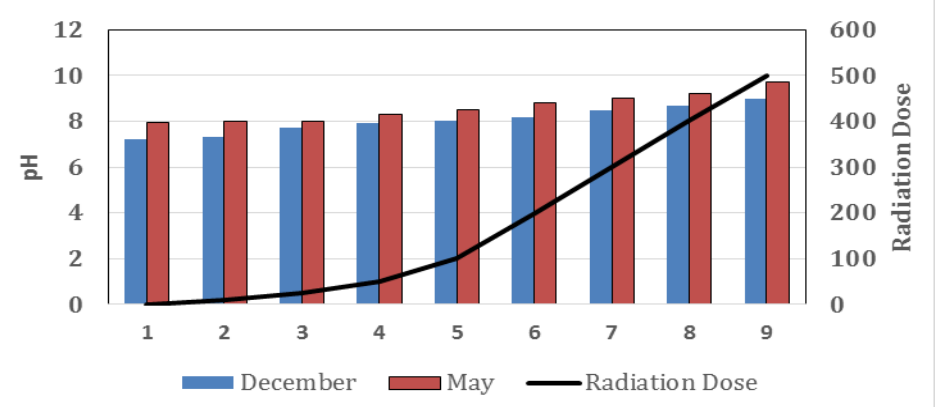

Figure 2: The $\mathrm{pH}$ values of radiation dose.

This increasing in $\mathrm{pH}$ value was attributed to the rise of $\mathrm{OH}$ extremists at bigger amounts as a result of the water hydrolysis. The highest value was recorded in May (9.4), while the lowest was in December (8.8). Sudan allowable limits of concentration for dispose treated wastewater to the surface water was 6-9.7 (table 1), the values of $\mathrm{pH}$ still within the permissible limits, as shown in tables 2 (Mottalib, 2017). Generally, pH values for normal water use should be above 6.00 and below 10.00 , while values above 10.00 are considered hazardous. The G-value of $\mathrm{OH}$ (G-OH is the basic unit of radiation chemical yield) in comparison with others extremists is in high level, which produced a large strength of free hydroxyl extremists in water thus raising the $\mathrm{pH}$ value.

Electrical conductivity (EC) and hardness measurement: Electrical Conductivity and Hardness of water investigated under one titled as they both have the role of melted ions in water. EC is the tool for measuring ability of solution for conducting electrolyte current which is significantly reliant on 
the offered of ions (Salem et al., 2011).

Conductivity in a liquid affected by availability of inorganic ions: Great level of EC is directly proportional to the abundance of inorganic ions in the wastewater. Electrical Conductivity and hardness trends are not affected by increasing radiation dose (figure 3\& 4).

This is attributed to the hydrolysis properties in water. Generally, inorganic salts are characterized by conductivity once dispersed in water because they are decomposed compared with organic materials. In addition to that, the doses of radiation did not break down the inorganic substances therefore the salts level does not vary with the rise in radiation dose. Therefore, Electrical Conductivity $(1120 \mu \mathrm{S} / \mathrm{cm})$ and hardness $\left(700 \mathrm{mg} / \mathrm{L}\right.$ as $\left.\mathrm{CaCO}_{3}\right)$ rates stayed unchanged throughout the different applied doses (table 2) (Mireles et al., 2004).

Turbidity: The effects of gamma radiation were studies under different radiation doses (figure 5). The results showed that a decrease in turbidity (90 NTU) in both May and December events were observed with increasing radiation dose till 50 krad, thereafter, start to rise per absorbing dose this because high doses of irradiation induced a precipitation reaction that was due to the liquefied organic substances in the sludge (figure 5) (Rehman et al., 2015).

Dissolved oxygen (DO): Physicochemical and biological actions taking place in the water environment influence the level of Dissolved Oxygen in water (State of Narragansett Bay and its Watershed, 2017). Concentrations of Dissolved oxygen are proportional to the amount of oxygen produced during the biological process of living organisms (Julian et al., 2018). Moreover, physicochemical factors in water like amount of salts and temperature strongly affect the dissolved oxygen (State of Narragansett Bay and its Watershed, 2017). Figure 6 depicted that there is a drop in the concentration of dissolved oxygen with increasing radiation doses.
Parameter

$\mathrm{pH}$

Total Suspended Solids (TSS) (mg/L)

Biochemical Oxygen Demand, BOD (mg/L)

Chemical Oxygen Demand, COD (mg/L)

Phenolic Compound (mg/L)

Fat, Oil, and Grease
Concentration, $\mathrm{mg} / \mathrm{L}$

6-9.7

30

30

150

0.50

10

Table 1: Permissible Limits of discharged wastewater to the surface water (Khogali and Riyadh, 2015)

\begin{tabular}{|c|c|c|c|c|c|}
\hline Factors & Months & Raw Value & Radiation Dose (krad) & Final value & Percentage (\%) \\
\hline \multirow[t]{2}{*}{$\mathrm{pH}$ (no units) } & May & 7.93 & 400 & 9.4 & - \\
\hline & December & 7.22 & 400 & 8.8 & - \\
\hline \multirow[t]{2}{*}{$\mathrm{EC}(\mu \mathrm{S} / \mathrm{cm})$} & May & 1120 & No effect & - & - \\
\hline & December & 790 & No effect & - & - \\
\hline Hardness (mg/l as & May & 700 & No effect & - & - \\
\hline $\left.\mathrm{CaCO}_{3}\right)$ & December & 550 & No effect & - & - \\
\hline \multirow[t]{2}{*}{ Turbidity (NTU) } & May & 200 & 50 & 90 & 55 \\
\hline & December & 150 & 25 & 90 & 40 \\
\hline Dissolved Oxygen (DO) & May & 15 & 50 & 10 & \\
\hline$(\mathrm{mg} / \mathrm{L})$ & December & 9 & 50 & 5 & \\
\hline \multirow[t]{2}{*}{ BOD5 (mg/L) } & May & 110 & 500 & 20 & 820 \\
\hline & December & 80 & 500 & 30 & 62.5 \\
\hline \multirow[t]{2}{*}{ COD (mg/L) } & May & 330 & 500 & 60 & 82 \\
\hline & December & 210 & 500 & 30 & 86 \\
\hline \multirow[t]{2}{*}{ TSS (mg/L) } & May & 147 & 50 & 20 & 86.4 \\
\hline & December & 114 & 100 & 30 & 73.7 \\
\hline \multirow[t]{2}{*}{ TDS (mg/L) } & May & 15300 & 25 & 1600 & 89 \\
\hline & December & 12600 & 10 & 800 & 93 \\
\hline \multirow{4}{*}{$\begin{array}{l}\text { Phenolic Compound } \\
\text { (mg/L) } \\
\text { FOG (mg/L) }\end{array}$} & May & 0.650 & 500 & 0.03 & 95.4 \\
\hline & December & 0.250 & 500 & 0.05 & 80 \\
\hline & May & 3500 & 500 & 200 & 94 \\
\hline & December & 2800 & 500 & 400 & 86 \\
\hline
\end{tabular}

Table 2: Physicochemical properties of the discharged wastewater to the surface water.

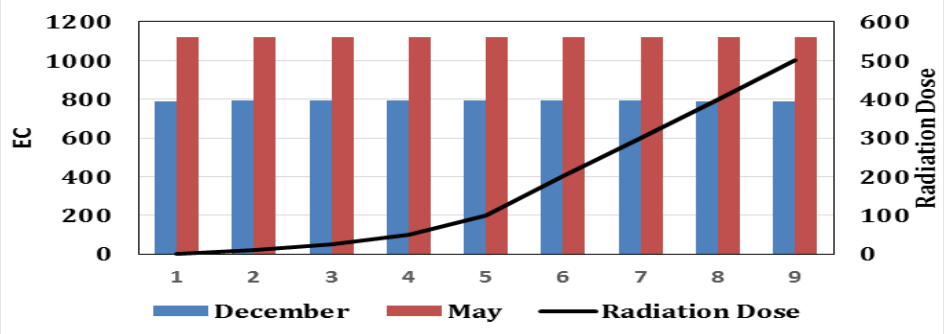

Figure 3: Electrical conductivity (EC) of radiated sample

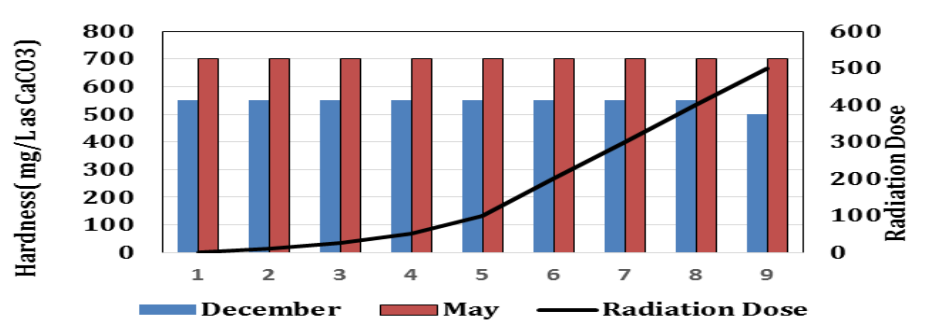

Figure 4: Hardness of radiated sample. 


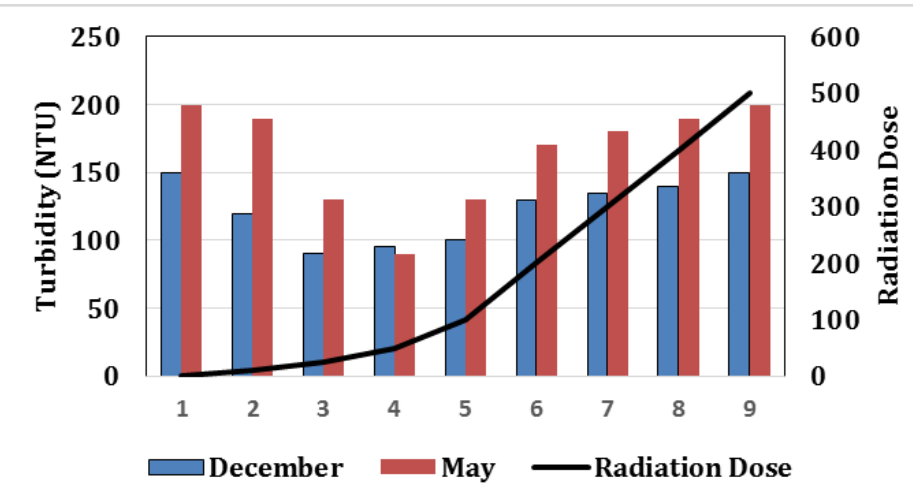

Figure 5: Turbidity of radiated sample.

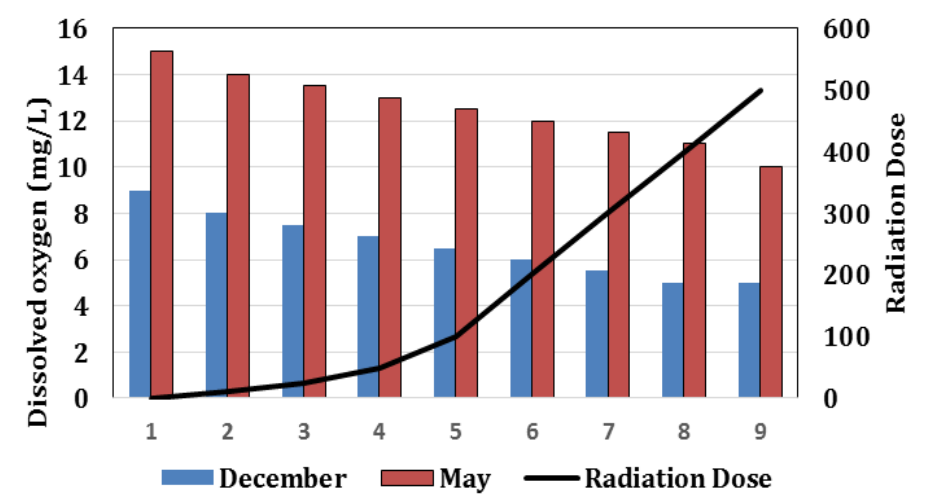

Figure 6: Dissolved oxygen (D0) of radiated sample.

The values of Dissolved Oxygen in the raw samples of wastewater were high and this due to the presence of primary aeration tank in Soba municipal station in Sudan. Alternatively, radioactive technique reduced Dissolved oxygen. This drop in the strength of dissolved oxygen caused by the following scenario: Solvated electrons that are built up during application of radiation doses in the liquid media. Therefore, the solvated electrons might interact by equilibrium reaction or attached to the molecular oxygen, so these electrons interfere with oxygen when hydrogen is available (Mohammed et al., 2006).

Biochemical oxygen demand (BOD5) measurement: BOD is the quantity of oxygen utilized by microflora to decay organic substances in water. This technique is used to verify the degree of contamination of a wastewater and the ability of a plant for treatment. Biochemical oxygen in water is basically determined by the difference in the oxygen in water samples preceding incubation and after incubation to 5 days. Figure 7 express a decrease in biochemical oxygen demand concentration regarding the rise of applied doses. This drop caused by the damage of microflora that utilized oxygen. It is well known that radiation pulses have detectable effects on living organisms. Furthermore, it can decompose organic compounds in the living organisms (table 2). The biochemical oxygen demand in 5 days achieved $20 \mathrm{mg} / \mathrm{L}$ using $500 \mathrm{krad}$ of gamma radiation, while the permissible value of $\mathrm{BOD}_{5}$ is $30 \mathrm{mg} / \mathrm{L}$, (table 1 \& 2). On the Other Hand, in December, the $\mathrm{BOD}_{5}$ concentration at the same radiation dose stayed high $(30 \mathrm{mg} / \mathrm{L})$, but they were within the permissible level $(30 \mathrm{mg} / \mathrm{L})$. This can be justified by the fact that some of the collected samples contain industrial chemicals and biological substances that cannot decomposed by radiation. To reduce these types of scenarios combined physicochemical methods should be activated (i.e., thermo processes and adsorption) (Sivinskih, 1975).

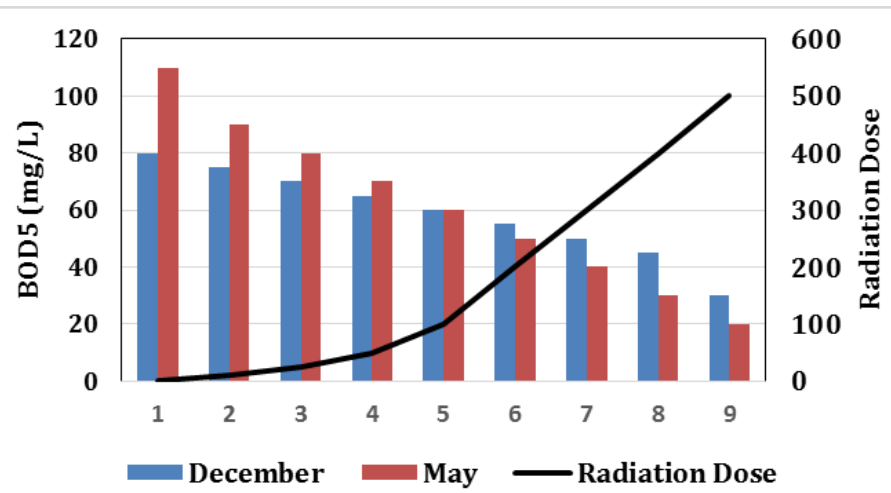

Figure 7: Biochemical oxygen demand (BOD5) of irradiated sample.

Chemical oxygen demand (COD): Is a tool for assessing of amount of oxygen corresponding to organic content of the sample that is liable to oxidation by a strong oxidant? It is a technique for determination the degree of pollution in water by organic substances (Sulaiman, et al., 2016). Generally, the COD value is greater than the BOD this due to the resistance created by part of organic substances to microorganism oxidation and therefore not engaged in biochemical oxygen demands could be simply oxidized. The value of chemical oxygen demand reflects the achievement of the permissible level for both May and December (figure 8).

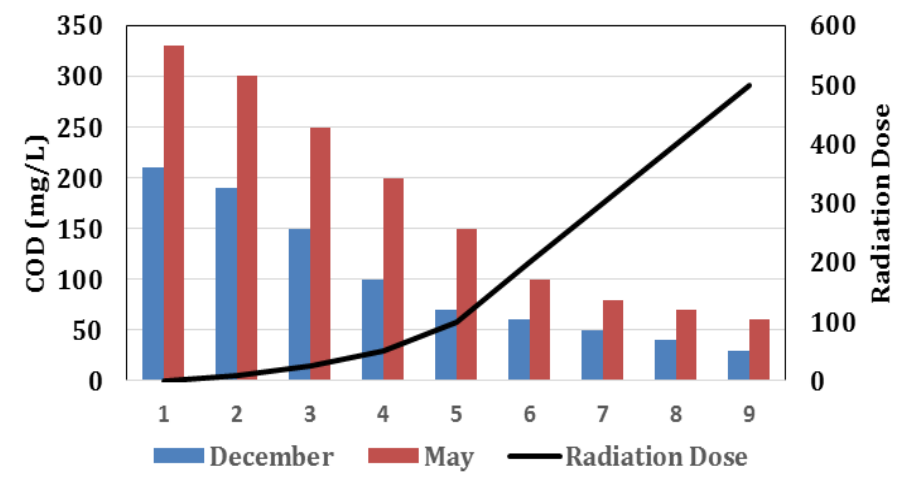

Figure 8: Chemical oxygen demand (COD) of irradiated sample. The COD in both May and December events keep decreasing pattern and approached $82 \& 86 \%$ removal of their initial value using $500 \mathrm{k}$ rad respectively, whereas the permissible limit of COD is $150 \mathrm{mg} / \mathrm{L}$, (table1\& 2). Nevertheless, in May, the COD strength at the same radiation dose stayed above, but they were within the permissible level $(30 \mathrm{mg} / \mathrm{L})$.

Total dissolved solid (TDS): TDS is an amount of organic and inorganic substances in a liquid. Figure 9 explore the mode of influences of radiation doses on total dissolved solids; it displayed that TDS concentration reduced with increasing in the doses of radiation to particular levels ( $25 \mathrm{Krad}$ ) for both May and December events then concentration of TDS improved with increasing in the doses of absorbed radiation. This could be attributed to the transformation of the liquefied organic materials to compounds of simple molecular weight. In addition to that high-level of radiation doses may have disbanded the suspended solids and sludge that were at the bottom of the container, thus increasing the concentration of TDS. The TDS levels never achieved the beginning values (Usharani et al., 2010). Our findings confirmed by other researchers' reports (Kaur et al., 2010). 


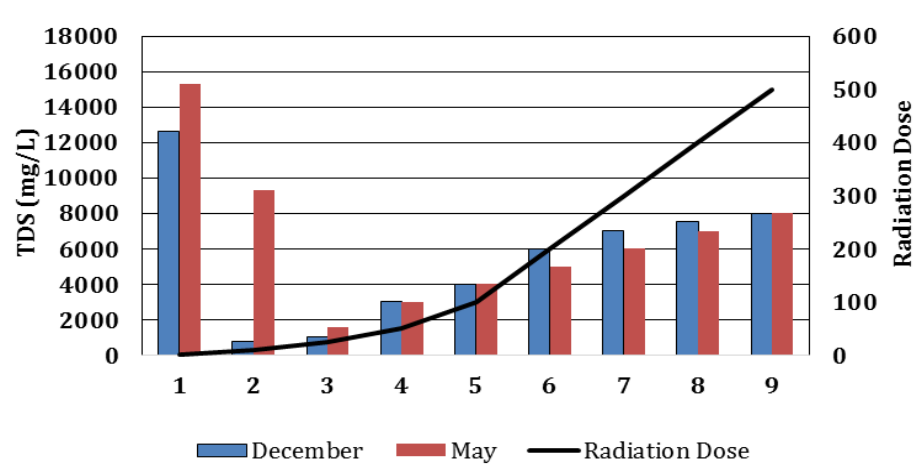

Figure 9: Total dissolved solids (TDS) of irradiated sample.

Total suspended solid (TSS): Suspended solids are the biggest sources of water pollution. It consists of an inorganic and an organic fraction. The inorganic part is almost greater than the organic one. Suspended solids play a vital role in the turbidity or cloudiness of the water. The result explores that a reduction trend of suspended solids (TSS) was observed with increasing absorbed radiation dose (figure 10).

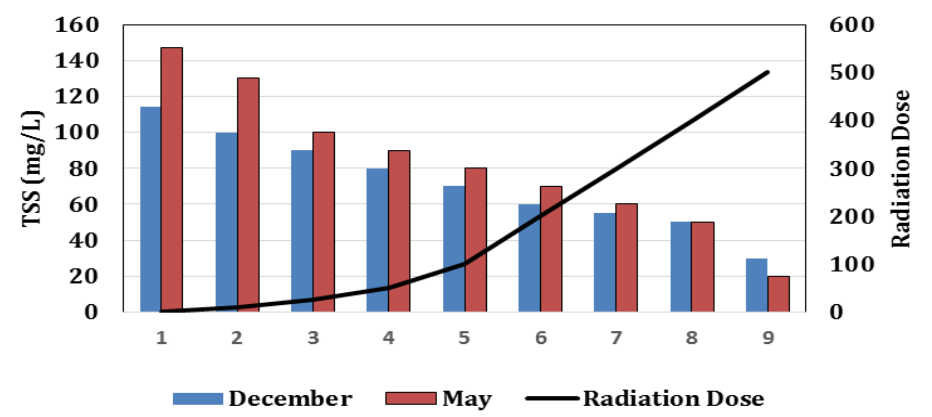

Figure 10: Total suspended solids (TDS) of irradiated sample. Both May and December events achieved removal rate of 86.4 and $73.7 \%$ respectively which is within the permissible range (table 1\& 2). This scenario of reduction in total suspended solids (TSS) was attributed to the conversion of TSS to the form of precipitate because of breaking down of organic materials and suspended particles in wastewater. Previous research reports confirmed our findings (Kaur et al., 2010; Olaoye and Oladeji, 2015; Chidozie and Nwakanma, 2017).

Fat, oil and grease (FOG): FOG is either in liquid or solid state, which is composed of long chains of hydrocarbons (Khwakaram, 2016). Concentration of Fat, Oil, \& Grease in this investigation was declined with increasing of radiation absorbed doses (figure 11). May and December events shows the reduction removal percentage of 94 and 86 respectively. The decrease in FOG concentration is generally attributed to the

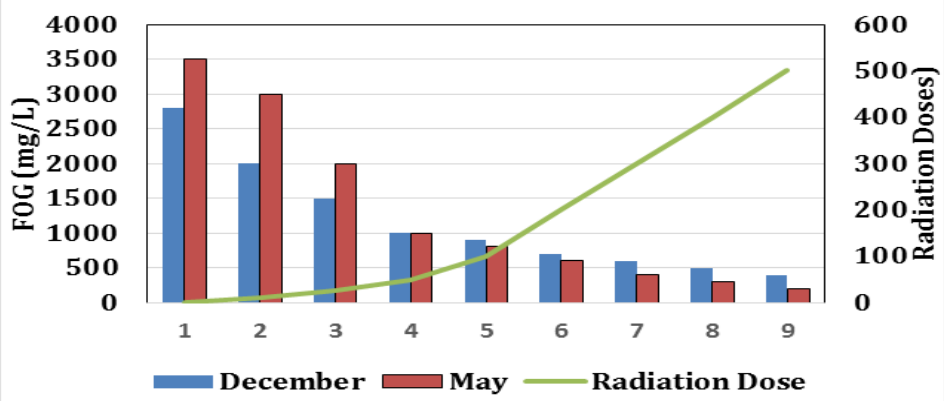

Figure 11: Fat, oil and grease (FOG) of irradiated sample. breakdown of the long bond of the hydrocarbon chain by radiation energy and converted the FOG to shorter hydrocarbon parts (Kaur et al., 2010; Olaniyi et al., 2012). Decomposition of FOG mostly lays on the availability of mineral Fat, Oil and Grease. Generally, radiation energy did not breaking down the mineral Fat, Oil and Grease (Khwakaram, 2016), and this compound did not show any environmental problems in the wastewater.

Phenolic compounds and standards of phenols: Phenolic substances are available in different industrial effluents (leather, Textile, pharmaceuticals, resin manufacturing, oil industries, petrochemicals, plastics, paint, pulp \& paper) (Kazemi et al., 2014; Mohammadi et al., 2015; Sun et al., 2015). Phenol has been chosen as a significance contaminant by the US Environmental Protection Agency (EPCRA, 2014; NPRI, 2009). Figure 12 showed that the total phenols content was reduced with increasing the radiation doses. The values of total phenols content are within the permissible level of discharging in surface water (table 1\&2). The percentage of removal of total phenol in May and December events were 95.4 and $80 \%$ respectively. It was further observed that treatment of total phenols with $500 \mathrm{krad}$ radiation dose is about to approach the entire break down of the initial phenol compound and achieved 95.4 and $80 \%$ total removals respectively (Karci et al., 2013).

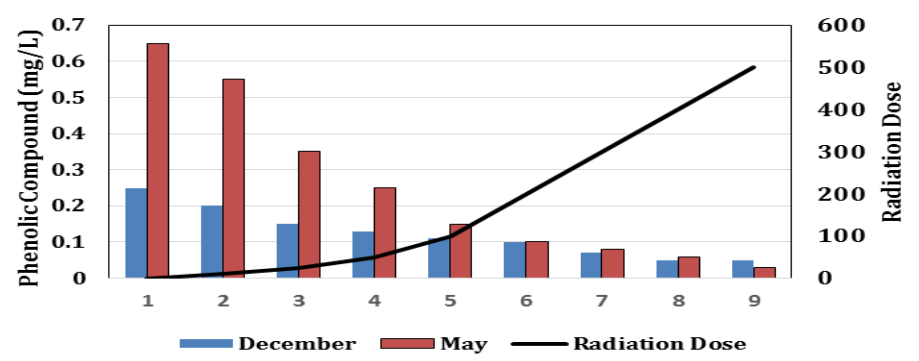

Figure 12: Phenolic standards concentration subjected to radiated doses.

ONCLUSION: This research project was performed to evaluate the effect of Irradiation by gamma radiation on physicochemical properties of wastewater collected from Soba municipal station in Khartoum-Sudan. This experiment confirmed that some physicochemical parameters like $\mathrm{pH}, \mathrm{DO}$, BOD5, COD, TSS, FOG, and Total phenols were decreased with increasing absorbed doses. Other parameters like Electrical Conductivity (EC) and Hardness were not affected by radiation doses, TDS, turbidity decreased up to $50 \mathrm{~K}$ rad and then increased with increased in radiation doses. All parameters are within the permissible level for discharge to surface water. Gamma-irradiation has shown to be effective in removing organic contamination from the sewage water and sludge. Gamma-irradiation opens door for possible reuse of irradiated sewage water and sludge. All the laboratory tested parameters, including sludge management should be considered in order to evaluate the multiple benefits of radiation technologically for treating municipal wastewater in Khartoum city.

CONFLICT OF INTEREST: Authors have no conflict of interest.

A CKNOWLEDGMENT: The authors wish to express their appreciation to Soba treatment plant and National Centre for research-Khartoum-Sudan for their financial support of this research.

R EFERENCES: Abo-El-Seoud, M., R. El-Motaium, M. I. Batarseh and R. Kreuzig, 2004. Impact of gamma radiation on the degradability of polynuclear aromatic hydrocarbons in 
Egyptian sewage sludge. Fresenius environmental bulletin, 13(1): 52-55.

Chidozie, K. and C. Nwakanma, 2017. Assessment of saclux paint industrial effluents on Nkoho River in Abia State, Nigeria. Journal of Ecosystem ecography, 7(2): 10-15.

Emergency Planningand Community Right-to-Know Act (EPCRA). 2014. Section 313 Chemical list for reporting year 2014. Availablefrom:http://www.epa.gov/toxics-release-inventory-triprogram/tri-chemical-list-ry--including-toxic-chemi categories.

Folin, O. and W. Denis, 1915. A colorimetric method for the determination of phenols (and phenol derivatives) in urine. Journal of biological chemistry, 22(2): 305-308.

Julian, K.T. S. Marianne, R. Shaun, 2018. Contaminated Groundwater Sampling and Quality Control. of Water Analyses. Environmental Geochemistry, 2nd ed.; British Geological Survey: Nottingham, UK, pp. 25-45.

Karci, A., I. Arslan-Alaton, T. Olmez-Hanci and M. Bekbolet, 2013. Degradation and detoxification of industrially important phenol derivatives in water by direct uv-c photolysis and h2o2/uv-c process: A comparative study. Chemical engineering journal, 224: 4-9.

Kaur, A., S. Vats, S. Rekhi, A. Bhardwaj, J. Goel, R. S. Tanwar and K. K. Gaur, 2010. Physico-chemical analysis of the industrial effluents and their impact on the soil microflora. Procedia environmental sciences, 2: 595-599.

Kazemi, P., M. Peydayesh, A. Bandegi, T. Mohammadi and 0. Bakhtiari, 2014. Stability and extraction study of phenolic wastewater treatment by supported liquid membrane using tributyl phosphate and sesame oil as liquid membrane. Chemical engineering research design, 92(2): 375-383.

Khogali, H. A. M. and K. Riyadh, 2015. Impact of khartoum refinery waste water pollutants on the environment. Pinnacle educational research development, 3(8): 809-818.

Khwakaram, A. I., 2016. Effects of fat, oil and grease (FOG) discharge pollutants on water quality of qalyasan stream, tanjero river and impact of fat, oil and grease on darbandikhan reservoir in sulaimani city-kurdistan region of Iraq. International journal of environment, ecology, family urban studies, 6(1): 1-7.

Mireles, A., C. Solıs, E. Andrade, M. Lagunas-Solar, C. Pina and R. Flocchini, 2004. Heavy metal accumulation in plants and soil irrigated with wastewater from mexico city. Nuclear instruments methods in physics research section b: beam interactions with materials atoms, 219: 187-190.

Mohammed, Y. A and F. R. Al-Khalidy. 2006. Use of Ionizing Radiation Technology for Treating Municipal Wastewater, International Journal of Environmental Research Public health, 3(4), 360-368.
Mohammadi, S., A. Kargari, H. Sanaeepur, K. Abbassian, A. Najafi and E. Mofarrah, 2015. Phenol removal from industrial wastewaters: A short review. Desalination water treatment, 53(8): 2215-2234.

Mottalib, M., 2017. Comparative study of water quality of Burigangaand Balu River Dhaka, Bangladesh. International journal of current research, 9(10): 59132-59137.

National Pollutant Release Inventory (NPRI) Substance List. 2009. Available from: https://ec.gc.ca/inrp-npri/default.asp ?lang=En\&n= E2BFC2DB-1.

Olaniyi, I., O. Raphael and J. O. Nwadiogbu, 2012. Effect of industrial effluent on the surrounding environment. Archives of applied science research, 4(1): 406-413.

Olaoye, R. and O. Oladeji, 2015. Preliminary assessment of effects of paint industry effluents on local groundwater regime in Ibadan, Nigeria. International journal of engineering research, 4(10): 518-522.

Rehman, M. Z.-u., M. Rizwan, A. Ghafoor, A. Naeem, S. Ali, M. Sabir and M. F. Qayyum, 2015. Effect of inorganic amendments for in situ stabilization of cadmium in contaminated soils and its phyto-availability to wheat and rice under rotation. Environmental science pollution research, 22(21): 16897-16906.

Salem, I. B., I. Ouardani, M. Hassine and M. Aouni, 2011. Bacteriological and physico-chemical assessment of wastewater in different region of Tunisia: Impact on human health. BMC research notes, 4(1): 144.

Salvatore, M.D., G. Carratù and G. Carafa. 2009. Assessment of heavy metals transfer from a moderately polluted soil into the edible parts of vegetables. Journal of food agriculture \& environment 7(1): 683-688.

Sivinskih, D., 1975. Treatment of sewage and sewage sludge with combination of heat and ionizing radiation (thermo radiation)", Sandia, Laboratories, USA,

State of Narragansett Bay and its Watershed. 2017. Technical Report. Chapter 15: Dissolved Oxygen. Available online: http://nbep.org/01/wp-content/uploads/2017/09/Bay-

Ecosystem-Condition-Indicators. Pdf (accessed on 20 December 2019).

Sulaiman, A.A.; Attalla, E.; Sherif, M.A.S. 2016. Water Pollution: Source and Treatment. Am. J. Environ. Eng, 6, 88-98.

Sun, X., C. Wang, Y. Li, W. Wang and J. Wei, 2015. Treatment of phenolic wastewater by combined uf and nf/ro processes. Desalination, 355: 68-74.

Usharani, K., K. Umarani, P. Ayyasamy, K. Shanthi and P. Lakshmanaperumalsamy, 2010. Physico-chemical and bacteriological characteristics of Noyyal river and ground water quality of Perur, India. Journal of applied sciences environmental management, 14(2): 11-25. 